not too pessimistic, Sir George being convinced that mankind has too much to lose if agreement fails for him not to believe that some way round would be found. Bertrand Russell's talk on the outlook for mankind is perhaps the most sombre of the series. $\mathrm{He}$ painted a picture, sober but realistic, of the consequences of failure to reach agreement and of the outcome of atomic war; and he urged, like Sir George Thomson, the adoption of an international system of control of the use of atomic energy as an immense advance towards security. Such control would make possible the peaceful use of the new discoveries without the constant menace of atomic 'Pearl Harbours'; it would demonstrate the possibility of international co-operation and would represent the first step in that limitation of national sovereignty without which nothing can be achieved. Like Prof. Falls, he insists on the impossibility of isolating the question of atomic energy, and emphasized that the real problem is to prevent great wars, for once they have begun no previous agreement will prevent the use of the most terrible weapons available.

Lord Russell based his main appeal on this point and the imperative need for drastic limitation of national sovereignty. He urged that it is the duty of those who realize the implications of modern weapons to devote themselves to a campaign of enlightenment addressed to the peoples of the West and the governments of the East. If mankind can be brought, while there is yet time, to realize that the most elementary motives of self-preservation demand this revolutionary change as regards national sovereignty, he believes a new era of unprecedented happiness and prosperity will almost inevitably result. It is necessary to overcome ancient loyalties, prejudices and deep-rooted suspicions, and to learn to think of mankind as a whole.

Sir John Anderson, in the concluding talk on British interests, does not take quite so grave a view, but his able summing up of the whole series emphasizes once more the impossibility of isolating atomic bombs from other weapons of war. He points out that in the Washington Declaration of November 1945, President Truman, Mr. Attlee and the Prime Minister of Canada pledged themselves to work for the elimination from the armouries of the nations not merely of the atomic bomb but also of all weapons of mass destruction. Like Lord Russell, he stresses the fact that the international body suggested as a means of protecting the world against the military use of atomic energy and encouraging its peaceful use would be something entirely new in human experience.

The ultimate choice before mankind is between a richer and a healthier world, and the virtual extinction of civilized life as we know it. That the choice should thus be put so fairly and squarely before every citizen is no mean contribution to the formation of enlightened public opinion; for it is on such opinion that every democratic government must rely, if it is to frame and pursue a policy of peace and co-operation, with all their implications, which these broadcasts so clearly displayed:

\section{ATOMIC SCIENTISTS' ASSOCIATION}

T $N$ the United States, the scientific workers concerned 1 in the investigation of nuclear fission in its application to the atomic bomb quickly banded together to make known their views on the scientific, social and international problems raised by the controlled release of atomic energy. In Britain, there were not so many with experience of the subject, and they were scattered up and down the country. Nevertheless, in the early summer of last year, the Atomic Scientists' Association came into being, with the main purpose of providing a forum for discussion of the subject.

In the recent series of broadcast talks on atomic energy, Sir George Thomson referred to the work which the Association is trying to do in Great Britain in impressing on public opinion generally, and on the Government in particular, the critical nature of the position. So far as scientific men themselves are concerned, there can be little question that they are awake to their social responsibilities in this matter, and endeavouring to induce their fellow citizens to consider realistically the new proposals and the departures from previous ideas and practice which the situation demands. That is indeed an encouraging feature of the situation. But the work and aims of the Atomic Scientists' Association deserve indeed to be much more widely known. They go far beyond the technical contributions the Association has already made to the development of an adequate plan of control, either for immediate action or for future operation.

Suggestions to these ends, such as are embodied in the Statement from the Council of Association printed in Nature earlier this year $(159,47$; 1947) come with the greater weight of authority in that the full membership of the Association is limited to men of science with first-hand and specialized knowledge of atomic energy. The Association can thus speak as a body of experts, and this considerably facilitates the furtherance of its aims of investigating and making proposals for the international control of atomic energy in order to assist in the solution of this most pressing problem, and of helping to shape the policy of Britain in all matters relating to atomic energy. For implementing that second aim, and still more that of bringing before the public of Great Britain the true facts about atomic energy and its implications, the necessarily small body of experts requires, however, the support of the much larger body of informed public opinion. This can be provided by enlarging the membership of the Association by the institution of 'associate members', consisting of scientific workers and others who may not have special knowledge of atomic physics but wish to be associated with policy in this field. An appeal for associate members has now been issued over the signature of Prof. N. F. Mott, president of the Association.

The letter in which this appeal is made points out that men of science believe themselves to be fitted to take the lead in these mattiers because, on the technical aspects of atomic energy, they are the best- 
informed body. Moreover, those who have been involved in the development of the atomic bomb are deeply concerned about the problems to which it has given rise ; before the War men of science took pride in the internationalism of their subject, and they are most anxious again to become a truly international body. To broaden the activities of the Association and especially to expand its publicity efforts, and to make the Association more effective, a large body of associate members is required. Such members will be in touch with the officers of the Association, and will receive free of charge all its publications, including the News Letter sent to full members. They can also write to the officers for advice about literature and information about atomic energy, and can express their own views and suggestions about the work of the Association. It is hoped that associate mermbers will contribute generously, as substantial funds are required for effective work by the Association; the annual subscription of one guinea, which should be sent with applications for associate membership to Dr. C. O. Jones, Atomic Scientists' Association, Clarendon Laboratory, Parks Road, Oxford, is regarded as a minimum.

This appeal deserves a generous response, which should be stimulated by the recent broadcasts on atomic energy. Hitherto, the average citizen in Great Britain has had to depend on the views of individuals given sporadically, for guidance in decisions on this important and urgent topic. The extension of the activities of the Atomic Scientists' Association now contemplated should make for the formation of a sound body of public opinion such as is necessary for the guidance of governments in these times.

\section{ANALYSIS AND PROPHECY IN SOCIAL STUDIES}

Studies in the Development of Capitalism

By Maurice Dobb. Pp. ix +396. (London: George Routledge and Sons, Ltd., 1946.) 18s. net.

\section{Revolution of Environment}

By E. A. Gutkind. (International Library of Sociology and Social Reconstruction.) Pp. $\mathrm{x}+454+74$ plates. (London : Kegan Paul and Co., Ltd., 1946.) 30s. net.

7 HOUGH widely different in subject-matter and approach, both these books are attempts to illuminate tendencies of the present by the analysis and synthesis of historical material, and both are concerned with the new opportunities for the development of civilization that now present themselves. In his introduction Dr. Gutkind directs attention to "the discrepancy between social conditions and the economic and technological possibilities" of the modern world, and calls for "an adjustment to new ways of life" by a "revolution of environment" that will produce a more balanced life within and between the nations. Mr. Dobb is concerned primarily with historical analysis, but he, too, has something to say of present trends, and his conclusions are of particular interest at a moment when the problems arising from a policy of 'full employment' and from the economic difficulties of Great Britain are so much in the air.
"Studies in the Development of Capitalism" is a work of synthesis rather than of original research, and Mr. Dobb as an economist is at pains in his introduction to placate both economists and historians who may feel that the book falls between two stools. $\mathrm{He}$ confesses, however, to "the obstinate belief that economic analysis only makes sense and can only bear fruit if it is joined to a study of historical development"; and, whatever the reader's view of his arguments and conclusions in detail, the result justifies the belief. In a series of studies Mr. Dobb sketches the development of capitalism from the decline of feudal society to the present day, showing the interplay of the various elements- the growth of the bourgeoisie and of the proletariat, the accumulation of industrial capital and the stimulus of invention and discovery-that together formed the capitalist system in its nineteenth-century heyday. His own definition of capitalism is essentially based on Marxist analysis, entailing as prerequisites of capitalist economy not merely the existence of the profit motive or of production for a distant market, but also the use of labour-power itself as a commodity, bought and sold by a limited class owning the means of production, and controlled by thè wage contract. Less narrow definitions, as Mr. Dobb himself admits, would carry the story of capitalism beyond the historical limits he sets himself, but the need, as he sees it, is for "a definition to describe the distinctive economic institutions of the modern world of recent centuries", and as, despite appearances, he disclaims any inten. tion of drawing frontiers between systems in history as "a sharp dividing line", he must be allowed his own definition. Of particular interest is the chapter on the "Growth of the Proletariat", in which Mr. Dobb stresses the point that it was factors other than the mere increase of population that produced the industrial proletariat of the nineteenth century : he neatly quotes J. S. Mill in support of the view that "it is influences affecting the proportion of the population in different social classes with which we are primarily concerned rather than influences affecting the size of the total population".

The general conclusion to which Mr. Dobb's argument leads is that "the economic situation of the hundred years between 1775 and 1875 was no more than a passing phase in the history of Capitalism, product of a set of circumstances which were destined, not only to pass, but in due course to generate their opposite", or, in the words of another writer, Prof. J. R. Hicks, whom he quotes, "nothing else but a vast secular boom". One therefore turns with interest to the last chapter, "The Period Between Two Wars", only to find little light on a confused period and a too ready identification of capitalism with Nazism. But it is, at any rate, clear that a process of development which has been going on for at least several centuries is now taking new forms, and $\mathrm{Mr}$. Dobb sees emerging a form of State capitalism wherein "the focus of attention has radically shifted, and it is on the incentive to Labour-a satisfaction of its claims to a larger share of income, of leisure, of control and to a higher status, as the prerequisite of its co-operation in production-that any discussion of economic policy ultimately turns". Whether that is the final word we cannot yet say : the challenge now is rather to Labour than to Capital.

There is little that is new in Mr. Dobb's material or presentation, nor does he claim originality. But his study of some of the strands that go to make up our modern economic life is an interesting one, though 